Research article

\title{
IN VIVO INVESTIGATION OF SOFT TISSUE RESPONSE OF NOVEL SILVER/POLY(VINYL ALCOHOL)/ GRAPHENE AND SILVER/POLY(VINYL ALCOHOL)/CHITOSAN/GRAPHENE HYDROGELS AIMED FOR MEDICAL APPLICATIONS - THE FIRST EXPERIENCE
}

\author{
LUŽAJIĆ BOŽINOVSKI Tijana ${ }^{1 *}$, MARKOVIĆ Danica ${ }^{1}$, TODOROVIĆ Vera ${ }^{2,3}$, \\ PROKIĆ Bolka Bogomir ${ }^{4}$, MILOŠEVIĆ Ivan ${ }^{1}$, DRNDAREVIĆ Neda ${ }^{5}$, NEŠOVIĆ \\ Katarina $^{6}$, KYONG Yop Rhee ${ }^{7}$, MIŠKOVIĆ-STANKOVIĆ Vesna ${ }^{6,7}$
}

\begin{abstract}
${ }^{1}$ Faculty of Veterinary Medicine, Department of Histology and Embryology, University of Belgrade, Bulevar oslobođenja 18, 11000 Belgrade, Serbia; ${ }^{2}$ Faculty of Stomatology Pančevo, Department of Histology and Embryology, University Business Academy in Novi Sad, Žarka Zrenjanina 187, 26000 Pančevo, Serbia; ${ }^{3}$ School of Medicine of University of Zenica, Department of Histology and Embryology, Travnička cesta 1, 72000 Zenica, Bosnia and Hercegovina; ${ }^{4}$ Faculty of Veterinary Medicine, Department of Surgery, Orthopedics and Ophthalmology, University of Belgrade, Bulevar oslobođenja 18, 11000 Belgrade, Serbia; ${ }^{5}$ Beo-Lab Laboratories, Medicover, Resavska 58-60, 11000 Belgrade, Serbia; ${ }^{6}$ Faculty of Technology and Metallurgy, University of Belgrade, Karnegijeva 4, 11000 Belgrade, Serbia; ${ }^{7}$ Department of Mechanical Engineering, Kyung Hee University, 17104 Yongin, South Korea
\end{abstract}

(Received 09 May, Accepted 23 July 2018)

In this paper, we have shown for the first time the soft tissue response of novel silver/ poly(vinyl alcohol)/graphene (Ag/PVA/Gr) and silver/poly(vinyl alcohol)/chitosan/ graphene (Ag/PVA/CHI/Gr) nanocomposite hydrogels aimed for medical applications. These novel hydrogels were produced by in situ electrochemical synthesis of silver nanoparticles in the polymer matrices as described in our previously published works. Both Ag/PVA/Gr and Ag/PVA/CHI/Gr, as well as controls Ag/PVA, Ag/PVA/CHI and commercial Suprasorb ${ }^{\odot}$ hydrogel discs, were implanted in the subcutaneous tissue of rats. Implants with the surrounding tissue were dissected after post-implantation on days 7, 15, 30 and 60 , and then processed for histological examination. The tissue irritation index (TIrI) score, according to ISO 10993-6, 2007, as well as the number of leukocytes in the peri-implant zone and connective tissue capsule thickness were examined. The results show that each TIrI score, the leukocyte number around the implanted materials and capsule thickness gradually decreased during the observation period. At the endpoint of follow-up, the $\mathrm{Ag} / \mathrm{PVA} / \mathrm{CHI} / \mathrm{Gr}$ implant was surrounded with a thinner capsule, while both the TIrI score and the number of leukocytes of the peri-implant zone were greater compared to the Ag/PVA/Gr implant. Despite the observed differences, we can conclude that our in vivo experiment suggested that both novel hydrogels were biocompatible and suitable for medical use.

Key words: biocompatibility, nanocomposite hydrogels, rat, soft tissue response

\footnotetext{
*Corresponding author: e-mail: ticavet@vet.bg.ac.rs
} 


\section{INTRODUCTION}

Regenerative medicine is a domain of great interest for medical researchers. The successful application of a medical device or implant depends on the properties of the biomaterials used to fabricate the device or implant, as well as on various other factors, including the manufacturing and processing of the implant materials, and the specific application in which the device is used [1]. Synthetic or natural polymers are a common base of such materials, because of their resemblance to real tissue. Hydrogels based on natural or synthetic polymers and their blends, are generally used for biomedical purposes. Their biocompatibility, hydrophilicity, and processability enable a wide range of applications.

Poly(vinyl alcohol) (PVA) is a synthetic polymer, which is commonly used in the preparation of biocomposites for various applications, such as wound dressings [2,3] and scaffolds for tissue engineering [4-6] due to its biocompatibility and non-toxicity. Due to their exceptional hydrophilicity, with many -OH groups on the side chain, PVA hydrogels are able to swell in aqueous solutions. This is particularly important for wound dressing applications, as the wound surroundings need to be kept moist at all times, and the hydrogel with a high water content can provide moisture and facilitate the removal of the dressing without damaging the wound tissue [7]. In addition, hydrogels are well suitable for tissue engineering applications, as their structure resembles that of soft tissue, and the porous matrices provide the appropriate environment for cell adhesion and tissue ingrowth [8,9]. A potential use of toxic cross linkers could also be eliminated by preparation of PVA hydrogels with a simple freezing-thawing method $[10,11]$.

Chitosan is a natural linear polysaccharide with a polycationic nature, comprised of $\beta$-(1-4)-linked D-glucosamine and $N$-acetyl-D-glucosamine units. It is obtained by partial or complete deacetylation of chitin, most commonly derived from crustaceans or fungi [12]. Due to the excellent biocompatibility and biodegradability, as well as to its natural antibacterial properties, chitosan has been used in various branches of tissue engineering and biomedicine [12,13]. Some examples of chitosan applications include wound dressings [14-17], tissue engineering [18,19], scaffolds or coatings for bone tissue implants [20-22] and drug delivery [23-25].

As a result of their unique properties, such as the antimicrobial activity against many microorganisms, silver nanoparticles (AgNPs) are especially attractive for use in medical applications $[26,27]$. AgNPs, however, tend to agglomerate due to their high surface energy, which leads to weakening of their antibacterial properties. This is why polymer-based stabilizers are frequently applied in order to lower their surface energy and to immobilize AgNPs in the polymer matrix. PVA is a polymer with many -OH groups on its chain that can act as binding sites for AgNPs and thus contribute to their stability inside the hydrogel [28]. Chitosan contains both $-\mathrm{OH}$ and $-\mathrm{NH}_{2}$ groups that allow binding to AgNPs and their further stabilization in the porous hydrogel matrix $[29,30]$. 
Graphene $(\mathrm{Gr})$ is a recently discovered material that has found frequent usage in biomedical applications $[27,28]$. Graphene is a two-dimensional (2D) monolayer of carbon atoms, stacked in a honeycomb lattice and this unique structure provides it with exceptional properties, such as high mechanical strength and great electrical and thermal conductivity [31,32]. All these properties could provide reinforcement to the polymeric materials, so graphene is often included in a polymer matrix as a nano-filler. The overall mechanical properties of the hydrogel matrices were shown to be improved by even small amounts of graphene in PVA/Gr hydrogels [33-35]. There is also a recent interest in the potential antibacterial activity of graphene [36], which could be beneficial for wound dressing or soft tissue implant applications, as these properties could provide additional bactericidal effects together with AgNPs, especially in the early phases of application to prevent biofilm formation. However, the antibacterial properties and specifically the mechanism of action is still debatable and somewhat controversial and more research, both in vitro and in vivo, is needed in this area of graphene application.

The aim of this study was to examine the impact of the incorporated graphene on the specific characteristics of $\mathrm{Ag} / \mathrm{PVA}$ and $\mathrm{Ag} / \mathrm{PVA} / \mathrm{CHI}$ nanocomposite hydrogels, as well as to examine the local response of the subcutaneous tissue after implementation of novel $\mathrm{Ag} / \mathrm{PVA} / \mathrm{Gr}$ and $\mathrm{Ag} / \mathrm{PVA} / \mathrm{CHI} / \mathrm{Gr}$ implants.

\section{MATERIALS AND METHODS}

\section{Material}

For the preparation and synthesis of nanocomposite hydrogels, the following chemicals were utilized: chitosan (CHI) powder (medium Mw, Sigma Aldrich, St. Louis, MO, USA), poly(vinyl alcohol) (PVA) powder (fully hydrolyzed, Mw $=70-100 \mathrm{kDa}$; Sigma Aldrich, St. Louis, MO, USA), graphene (Gr) nanopowder (Graphene Supermarket, Calverton, NY, USA), silver nitrate (M. P. Hemija, Belgrade, Serbia), potassium nitrate (Centrohem d.o.o., Stara Pazova, Serbia), glacial acetic acid (Betahem d.o.o., Belgrade, Serbia). Ultra-pure water (Milli-Q system, Millipore, Burlington, MA, USA) was used in all experiments.

\section{Preparation of PVA, PVA/Gr, PVA/CHI and PVA/CHI/Gr hydrogels}

PVA and PVA/Gr hydrogels were prepared according to the procedure published elsewhere [37-39]. PVA/CHI and PVA/CHI/Gr hydrogels were obtained following similar procedure [30].

\section{Electrochemical synthesis of Ag/PVA, Ag/PVA/Gr, Ag/PVA/CHI and Ag/ PVA/CHI/Gr nanocomposite hydrogels}

For the synthesis of silver nanoparticles (AgNPs), the PVA, PVA/Gr, PVA/CHI and PVA/CHI/Gr hydrogels were cut into discs with an approximate diameter of 
$5 \mathrm{~mm}$ and width of $2 \mathrm{~mm}$ (appropriate dimensions for in vivo experiments). Before the electrochemical synthesis, the discs were immersed in $0.25 \mathrm{mM} \mathrm{AgNO}_{3}$ swelling dispersions, with $0.1 \mathrm{M} \mathrm{KNO}_{3}$ added to ensure better electrical conductivity. The containers with hydrogel discs in swelling dispersions were kept at $48 \mathrm{~h}$ in a dark place, to achieve the equilibrium swelling of the samples. In situ electrochemical synthesis of AgNPs was performed by electrochemical reduction of $\mathrm{Ag}^{+}$ions at constant voltage inside the PVA, PVA/Gr, PVA/CHI and PVA/CHI/Gr polymer matrices. A custom made glass electrochemical cell was used, with two horizontal Pt plates as working and counter electrodes, between which the hydrogel samples were placed in a sandwich-like setup. The MA 8903 Electro-Phoresis Power Supply (Iskra d.d., Ljubljana, Slovenia) was used for the electrochemical synthesis. The synthesis was carried out at $90 \mathrm{~V}$ with implementation time of $4 \mathrm{~min}$, and the polarity of the electrodes was reversed every 1 min. Before and after every experiment, the electrodes were cleaned with $\mathrm{HNO}_{3}(1: 1)$ and distilled water.

\section{In vivo experiment}

Sterilized Ag/PVA, Ag/PVA/Gr, Ag/PVA/CHI and Ag/PVA/CHI/Gr nanocomposite hydrogel discs, as well as commercial Suprasorb $\mathrm{C}$, a calcium alginate dressing (Lohmann \& Rauscher GmbH \& Co. KG, Neuwied, Germany) were implanted in the subcutaneous tissue of 16 anesthetized adult females. A small skin incision on the rat back, at the level of the midline of the thoracic spinal column, was made to create five pockets in the subcutis of back lateral sides, which distanced $3 \mathrm{~cm}$ from the back midline. The pockets were directed cervically and lumbally, so the distance between implanted material areas was about 3 to $3.5 \mathrm{~cm}$ (Fig. 1A) the implants were introduced through the pockets. A surgical incision made on the right lateral side opposite of the Suprasorb (C) implantation represented the control area. The experiment lasted 60 days. Surgical implantation of hydrogels was done according to the permeation of the Ethical Committee of the Faculty of Veterinary Medicine, University of Belgrade.
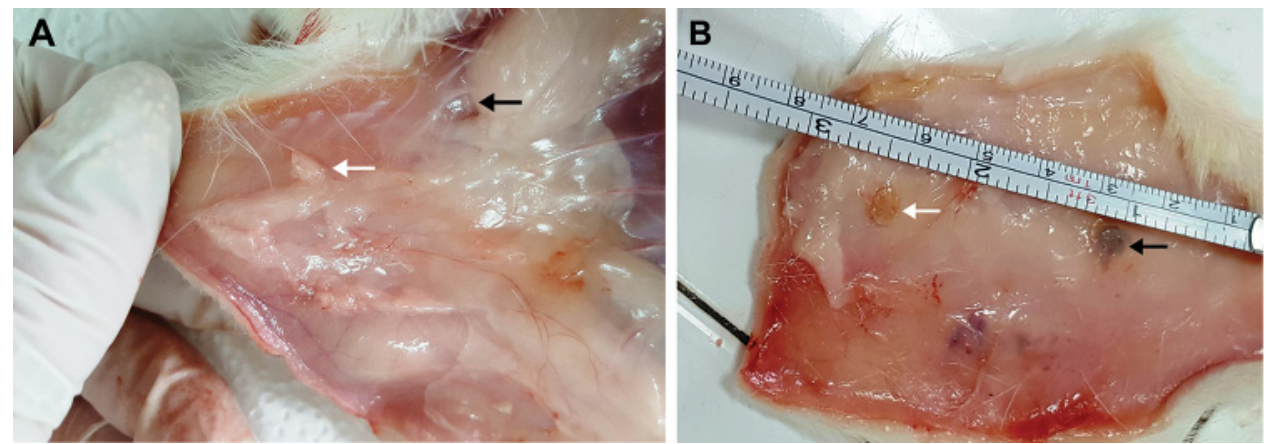

Figure 1. The appearance of $\mathrm{Ag} / \mathrm{PVA} / \mathrm{Gr}$ and $\mathrm{Ag} / \mathrm{PVA} / \mathrm{CHI} / \mathrm{Gr}$ implants during surgical intervention, immediately after implantation (A) and at postimplantation day 60 (B). Black and white arrows indicate $\mathrm{Ag} / \mathrm{PVA} / \mathrm{Gr}$ and $\mathrm{Ag} / \mathrm{PVA} / \mathrm{CHI} / \mathrm{Gr}$ respectively, at both presented periods (A and $\mathrm{B})$. 
All animals survived the surgery. No wound healing complications were observed after the surgery and during the whole experiment. The experimental materials were retrieved from the rats after post-implantation day (p.i.d.) 7, 15, 30 and 60, and there were thus four subgroups of animals corresponding to the different periods, i.e. each subgroup consisted of four animals. After the endpoint of the above mentioned experimental periods, the animals were sacrificed and implants with the surrounding tissue were dissected, fixed, and processed by conventional procedures for histological examination. At each end point of the experiment, including postoperative day 60 , the distance between implants corresponded to that of implantation time, and we did not notice that implant come close to each other or were joining (Fig. 1B).

\section{Histological examination}

\section{Tissue processing for light microscopy}

Tissue paraplast blocks were serially sectioned stained with Hematoxylin-Eosin (H\&E) and Van Gieson staining protocols, and then were evaluated under a light microscope. However, for histomorphometry, only sections with the largest length and width diameters of the implanted discs were collected.

\section{Morphological examination}

In order to estimate the processes of tissue response, regeneration and the tissueimplant interface, the obtained slides were examined semiquantitatively by following histological reactions: epithelial alterations, relative number of inflammatory cells, vascular congestion, edema, and the presence and connective tissue capsule thickness. All these parameters were presented as the tissue irritation index (TIrI) score, according to the ISO 10993-6, 2007. The TIrI was as follows: the value of 1 to 5,6 to 10,11 to 15 , and 16 to 20 indicates minimal, mild, moderate and severe tissue responses, respectively.

\section{Histomorphometry}

Morphometric methods included: 1) counting the number of inflammatory cells in the peri-implanted area and 2) measuring the capsule thickness. The capsule thickness was measured with an ocular micrometer, at x 100 magnification. The total capsule thickness from four sides (upper-lower-right-left) was measured, and the mean value of these measurements was obtained. The number of inflammatory cells of the periimplant area was counted in five representative zones of each specimen, by using ocular grids which consist of a square limiting test area of $0,250 \mathrm{~mm}^{2}$, at magnification of 40x. The results were expressed as the number of inflammatory cells per $\mathrm{mm}^{2}$ of profile area. All sections were examined using standard Olympus BX-41 microscope and archived with Olympus XC50 digital camera, using the CellSens Entry software (Olympus, Tokyo, Japan). 


\section{Statistical analysis}

The data were analyzed in the statistical software package IBM SPSS 20. Analysis of variance for repeated measurements was performed within the general linear model. All results are expressed as mean $\pm \mathrm{SE}$. The minimum level of statistical significance was set at $\mathrm{p}<0.05$.

\section{RESULTS}

\section{Soft tissue response - general observation during the post-implantation period for all implanted hydrogels}

\section{Total irritation index score}

Semiquantitative evaluation of the local soft tissue reaction (i.e. TIrI score) to the subcutaneously implanted Ag/PVA, Ag/PVA/Gr, Ag/PVA/CHI, Ag/PVA/CHI/ Gr and Suprasorb ${ }^{\odot}$ hydrogels, as well as tissue reaction at pseudooperated regions (incision skin) is shown in Fig. 2.

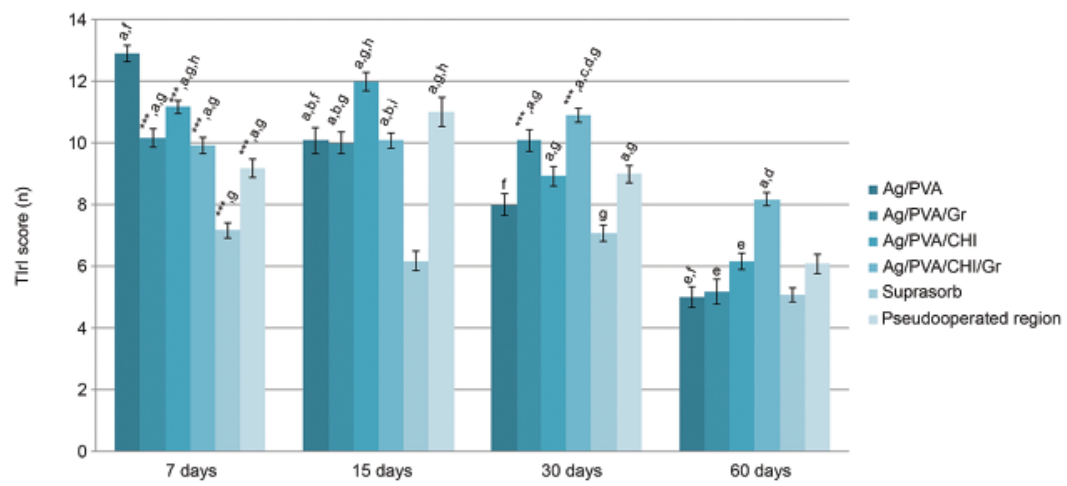

Figure 2. TIrI score for all examined implanted biomaterials and control area of skin incision. $* * * \mathrm{p}<0.001$ relative to Ag/PVA; $\mathrm{a}-\mathrm{p}<0.001$ relative to Suprasorb; $\mathrm{b}-\mathrm{p}<0.01$ relative to Ag/ PVA/CHI; $\mathrm{c}-\mathrm{p}<0.001$ relative to Ag/PVA/CHI; $\mathrm{d}-\mathrm{p}<0.001$ relative to Pseudooperated region; $\mathrm{e}-\mathrm{p}<0.001$ relative to $\mathrm{Ag} / \mathrm{PVA} / \mathrm{CHI} / \mathrm{Gr} ; \mathrm{f}-\mathrm{p}<0.001$ relative to all other observed periods; $\mathrm{g}-\mathrm{p}<0.001$ relative to 60 days; $\mathrm{h}-\mathrm{p}<0.001$ relative to 30 days; $\mathrm{i}-\mathrm{p}<0.01$ relative to 60 days.

Firstly, there was not strong tissue response to different implanted materials in any of the observed periods, and necrosis of surrounded peri-implant tissue was not observed. Secondly, the results show that the TIrI scores, after the type of hydrogels applied, in each observation period were between the minimal and mild value limits, except for the p.i.d. 7 in the case of implanted Ag/PVA, the p.i.d. 7 and 15 in the case of implanted Ag/PVA/CHI, and p.i.d. 30 in the case of implanted Ag/PVA/CHI/ $\mathrm{Gr}$, when registering moderate tissue reactions. Thirdly, at the end of the observed period, the tissue response to the implanted materials was minimal or mild. Finally, 
at the end of the observation period, the smallest TIrI was recorded in the case of implanted Ag/PVA and Ag/PVA/Gr hydrogels, and these values did not differ from the control values. Ag/PVA/CHI/Gr was the only material which had significantly higher values of TIrI scores at the end of the observation period compared to the implanted materials, including Suprasorb ${ }^{\odot}$ or the control pseudooperated region.

\section{Leukocyte infiltration}

The leukocyte number around the implanted materials was the highest at p.i.d. 7 compared to all other periods $(\mathrm{p}<0.001)$ and gradually decreased during the observation period, with a certain deviation in the case of implanted $\mathrm{Ag} / \mathrm{PVA} / \mathrm{CHI} / \mathrm{Gr}$. In addition, in all observed periods, there were significantly higher leukocyte numbers around each of the implanted materials compared to the implanted Suprasorb ${ }^{\odot}(p<0.01)$, with the exception on p.i.d. 60 , when no significant differences were recorded between the Suprasorb $^{\odot}$ and $\mathrm{Ag} / \mathrm{PVA}$ hydrogels. In addition, it can be noted that implantations of the hydrogels in each observed period caused a lower inflammatory response in comparison to incision surgery $(\mathrm{p}<0.01)$, with the exception of $\mathrm{Ag} / \mathrm{PVA} / \mathrm{CHI} / \mathrm{Gr}$ implant at p.i.d. 60 , when the number of leukocytes was significantly higher $(\mathrm{p}<0.001)$ (Fig. 3).

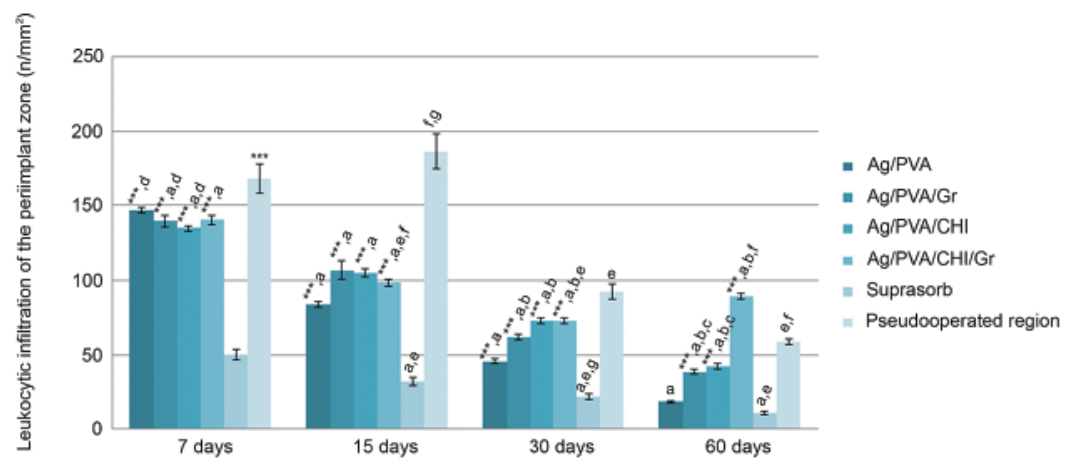

Figure 3. Leukocytic infiltration of the peri-implant zone for all examined biomaterials and control area of skin incision. ${ }^{* * *} \mathrm{p}<0.001$ relative to Suprasorb; $\mathrm{a}-\mathrm{p}<0.001$ relative to Pseudooperated region; $\mathrm{b}-\mathrm{p}<0.001$ relative to $\mathrm{Ag} / \mathrm{PVA} ; \mathrm{c}-\mathrm{p}<0.001$ relative to $\mathrm{Ag} / \mathrm{PVA} /$ $\mathrm{CHI} / \mathrm{Gr} ; \mathrm{d}-\mathrm{p}<0.001$ relative to all other observed periods; $\mathrm{e}-\mathrm{p}<0.001$ relative to 7 days; $\mathrm{f}-$ $\mathrm{p}<0.001$ relative to 30 days; $\mathrm{g}-\mathrm{p}<0.05$ relative to 60 days.

\section{Connective tissue capsule}

During the first weeks after surgery, the site of implantation was embedded with a connective tissue capsule in a similar way for each of the implanted materials, and thus isolated from the surrounding tissues. A progressive increase of connective tissue capsule thickness around each implanted material was observed from day 7 to day 30, but after that the thickness of the capsule decreased over time and finally, at p.i.d. 60, it reached the mean dimensions between $33 \pm 2.39$ and $70 \pm 2.68 \mathrm{~mm}$ for implanted Suprasorb $^{\odot}$ and $\mathrm{Ag} / \mathrm{PVA} / \mathrm{Gr}$, respectively. The capsule thickness in all examined 
periods after implantation was the highest in the case of implanted Ag/PVA/Gr. During the observation period, the thinnest capsules around $\mathrm{Ag} / \mathrm{PVA} / \mathrm{CHI}$ were at the 30th day after surgery, as well as surrounding $\mathrm{Ag} / \mathrm{PVA} / \mathrm{CHI}$ and Suprasorb ${ }^{\odot}$ on the 60th day after surgery (Fig. 4).
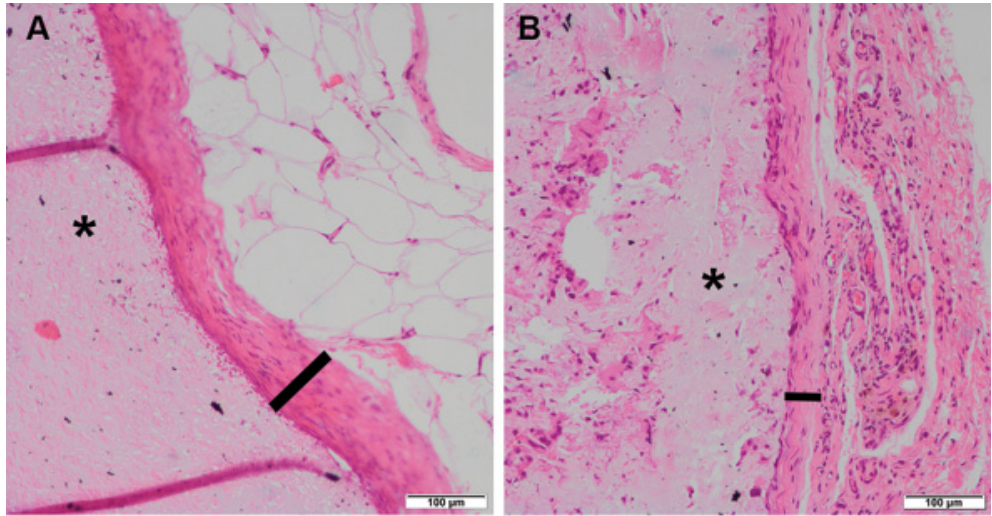

C

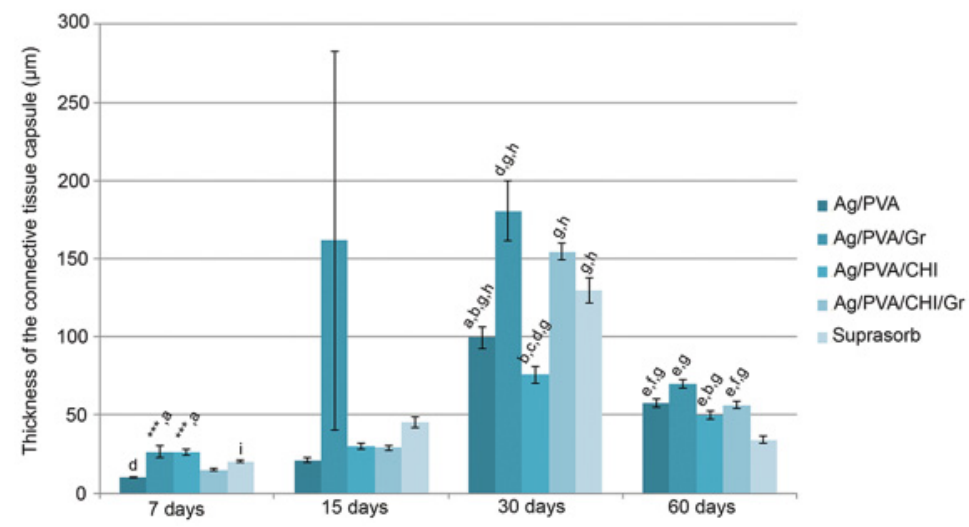

Figure 4. Tissue capsule thickness (dash) around implanted $\mathbf{A}-\mathrm{Ag} / \mathrm{PVA} / \mathrm{Gr}$ and $\mathbf{B}-\mathrm{Ag} /$ PVA/CHI/Gr hydrogels (star) at postimplantation day 60. The pictures show that Ag/PVA/ $\mathrm{CHI} / \mathrm{Gr}$ implant was surrounded with a thinner capsule than Ag/PVA/Gr implant. H\&E, bar: $100 \mu \mathrm{m} ; \mathbf{C}-$ Connective tissue capsule thickness for all implanted biomaterials. ${ }^{* * *} \mathrm{p}<0.001$ relative to $\mathrm{Ag} / \mathrm{PVA}$; $\mathrm{a}-\mathrm{p}<0.01$ relative to $\mathrm{Ag} / \mathrm{PVA} / \mathrm{CHI} / \mathrm{Gr} ; \mathrm{b}-\mathrm{p}<0.001$ relative to $\mathrm{Ag} /$ PVA/Gr; $\mathrm{c}-\mathrm{p}<0.001$ relative to Ag/PVA/CHI/Gr; $\mathrm{d}-\mathrm{p}<0.05$ relative to Suprasorb; $\mathrm{e}-$ $\mathrm{p}<0.001$ relative to Suprasorb; $\mathrm{f}-\mathrm{p}<0.01$ relative to $\mathrm{Ag} / \mathrm{PVA} / \mathrm{Gr} ; \mathrm{g}-\mathrm{p}<0.001$ relative to 7 days; $\mathrm{h}-\mathrm{p}<0.001$ relative to 60 days; $\mathrm{i}-\mathrm{p}<0.01$ relative to 60 days.

Both macrophages and giant cells were seen in the connective tissue capsule surrounding each implanted material in any examined period.

\section{Tissue reaction in the case of implantations of Ag/PVA versus Ag/PVA/Gr}

Ag/PVA implantation induced the strongest tissue response at p.i.d. 7 (TIrI 13 \pm 0.26$)$, and it was significantly higher in relation to all observed periods, as well as with 
comparison to all other implanted hydrogels or pseudooperated regions $(\mathrm{p}<0.001)$. However, after this, the tissue response to $\mathrm{Ag} / \mathrm{PVA}$ progressively decreased up to p.i.d. 60, where TIrI score $(5.00 \pm 0.35)$ had a minimal level and similar value to Suprasorb ${ }^{\odot}$ and the pseudooperated region.

In contrast, monitoring of the tissue response dynamic during the $\mathrm{Ag} / \mathrm{PVA} / \mathrm{Gr}$ implantation demonstrated that this biomaterial caused induction a far smaller tissue response at p.i.d. 7 compared to implanted Ag/PVA. Also, the degree of tissue response to this biomaterial was unchanged during the first 30 days, but significantly higher $(\mathrm{p}<0.001)$ than the value observed at p.i.d. 60. Specifically, at p.i.d. 60, TIrI in the case of $\mathrm{Ag} / \mathrm{PVA} / \mathrm{Gr}$ hydrogels was similar to both Ag/PVA and Suprasorb ${ }^{\odot}$ implantations as well as the control pseudooperated region (Fig. 2).

However, there was a higher leukocyte number in the peri-implant area surrounding Ag/PVA/Gr than Ag/PVA at both p.i.d. 30 and $60(\mathrm{p}<0,001)$ (Fig. 3). Similarly, throughout the monitoring period, there was a significantly thicker capsule surrounding the implanted Ag/PVA/Gr compared to Ag/PVA (p<0.001) (Fig. 4).

\section{Tissue reaction in the case of implantations of Ag/PVA/CHI versus Ag/PVA/CHI/Gr}

$\mathrm{Ag} / \mathrm{PVA} / \mathrm{CHI}$ implantation induced the strongest tissue response at p.i.d. 15, while in the case of $\mathrm{Ag} / \mathrm{PVA} / \mathrm{CHI} / \mathrm{Gr}$ implantation this response was somewhat delayed and strongest at p.i.d. 30. After these observed peaks, there were significantly reduced tissue reactions at the end of the observed period for both implanted materials, and the degree of reduction was significant compared to each previous observation period $(\mathrm{p}<0.001)$. However, at p.i.d. 30 and 60, TIrI scores in the cases of implanted Ag/ PVA/CHI/Gr were significantly higher in comparison with the control values, as well as in relation to implanted $\mathrm{Ag} / \mathrm{PVA} / \mathrm{CHI}(\mathrm{p}<0.001)$ (Fig. 2).

Leukocyte infiltration of the peri-implant zone was gradually decreased during the entire monitoring period in the case of implanted Ag/PVA/CHI $(\mathrm{p}<0.001)$. However, in the case of implanted $\mathrm{Ag} / \mathrm{PVA} / \mathrm{CHI} / \mathrm{Gr}$ there was an increase in leukocyte infiltration at p.i.d. 60. Also, although this increase was significant in relation to the previous study period $(\mathrm{p}<0.001)$, the leukocyte number was significantly lower compared to the highest values observed at p.i.d. 7 ( $p<0.001)$ (Fig. 3).

The thickness of the capsule was significantly increased during the first 30 days after implantation ( $<<0.001$; p.i.d. 30: p.i.d. day 7 ), and then was decreased at p.i.d. 60 , in cases of both implanted Ag/PVA/CHI or Ag/PVA/CHI/Gr. Although the thickness of the capsule around the implanted $\mathrm{Ag} / \mathrm{PVA} / \mathrm{CHI} / \mathrm{Gr}$ was significantly higher compared to the implanted $\mathrm{Ag} / \mathrm{PVA} / \mathrm{CHI}$ at p.i.d. 30 ( $\mathrm{p}<0.001)$, this difference was lost at p.i.d. 60. However, the thickness of the capsules of both implanted materials remained significantly higher in relation to the capsule surrounding the implanted Suprasorb $^{\odot}(\mathrm{p}<0.001)$, and significantly higher than the initial values at p.i.d. 7 $(\mathrm{p}<0.001)$ (Fig. 4). 


\section{$\mathrm{Ag} / \mathrm{PVA} / \mathrm{Gr}$ versus Ag/PVA/CHI/Gr - in vivo soft tissue response differences after implantation of these novel hydrogels}

According to TIrI score, the tissue response was far more strong at p.i.d. 60 in the case of implanted $\mathrm{Ag} / \mathrm{PVA} / \mathrm{CHI} / \mathrm{Gr}$ in comparison to implanted $\mathrm{Ag} / \mathrm{PVA} / \mathrm{Gr}$ $(\mathrm{p}<0.001)$ (Fig. 2). A similar situation exists with regard to the degree of leukocyte infiltration. (Fig. 3). However, the $\mathrm{Ag} / \mathrm{PVA} / \mathrm{CHI} / \mathrm{Gr}$ implant was surrounded with a thinner capsule than $\mathrm{Ag} / \mathrm{PVA} / \mathrm{Gr}$ during all examined periods, and this difference is statistically significant at both the beginning and the end points of the follow-up period $(\mathrm{p}<0.01)$ (Fig. 4).

\section{Degradation of implanted hydrogels}

Macrophages penetrated all implanted hydrogels at the beginning of the monitoring period, and they were observed both in the periphery and the deeper zones of implanted materials during follow-up (Fig. 5). There are vacuoles with phagocytosed materials in the cytoplasm of these macrophages.
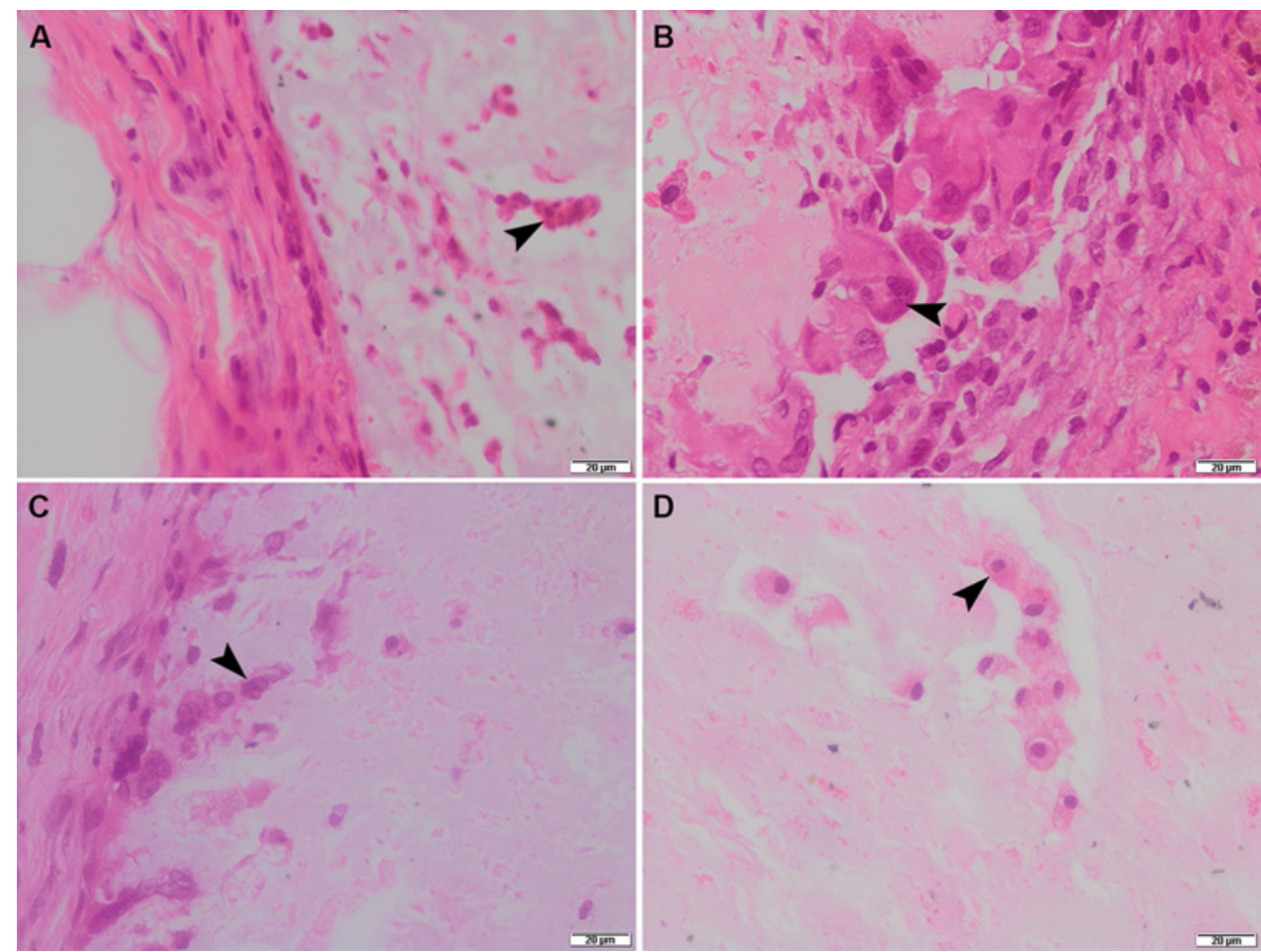

Figure 5. Implanted $\mathrm{Ag} / \mathrm{PVA} / \mathrm{CHI} / \mathrm{Gr}$ resorption by giant cells or macrophages (arrows) activities during follow-up period. H\&E, bar: $20 \mu \mathrm{m}$. A -7 days, $\mathbf{B}-15$ days, $\mathbf{C}-30$ days, D - 60 days. 


\section{DISCUSSION}

In this study, we investigated the biocompatibility of novel polymers based on PVA or PVA/CHI hydrogels with silver nanoparticles (AgNPs), in which graphene was incorporated to improve their properties. There are several studies of $\mathrm{Ag} / \mathrm{PVA} / \mathrm{Gr}$ [33,40-43], and $\mathrm{Ag} / \mathrm{PVA} / \mathrm{CHI} / \mathrm{Gr}$ polymers [30,39,44], however, none provides information regarding their in vivo biocompatibility. For this reason, our in vivo investigations of novel Ag/PVA/Gr and Ag/PVA/CHI/Gr hydrogels with improved physical properties should be the basis for further preclinical and clinical research with the goal of their application in human and veterinary medicine.

Given the small amounts of the gelling agent and the high content of liquids (up to $99 \%$ ), the hydrogels have a density close to water density, but possess the structural bonding of a solid substance. Polymeric hydrogels may be natural (including chitosan) or synthetic (including PVA) [45].

The simple structure and unique properties of PVA polymers such as adhesion, strength, film formation, hydrophilicity but very low swelling capacity (due to their sensitivity to hydrogen bonding and over-crystallization), biocompatibility, safety and non-cancerous properties, make them desirable for specific biomedical applications [46]. To date, many uses of PVA hydrogels have been proposed in biomedicine, including their use as soft materials for building contact lenses [47], artificial cornea [48], artificial cartilage and meniscus [49,50], tendon and bone regeneration [51,52], hydrogel coating of the humeral head surface in shoulder joint prosthesis [53], for suppressing the formation of adhesions in peritonitis [54], vehicle for medicaments, including prolonged release of antibiotics in veterinary medicine $[55,56]$, cell growth substrate [57], for prostate brachytherapy preparations [58], cardiovascular grafts [59], and other. It is necessary to look with great optimism at the results of the first clinical study with long-term follow-up (5-8 years) of the commercial PVA (Cortiva, RTI Surgical Inc., FL, USA) implant success in focal cartilage defects. These results showed that synthetic PVA hydrogel implants guarantee functional recovery of a knee joint in mid-life patients with focal lesions of the cartilage [60]. The first preliminary results of a clinical study on repairing the human joint surface metacarpal bone by implantation of PVA in patients with osteoarthritis were published [61]. Also, excellent clinical results five years after PVA hydrogel hemiarthroplasty of the first metatarso-phalangeal joint in advanced hallux rigidus were obtained [62].

However, physical properties of PVA hydrogels are generally reversible which disrupts their stability [45]. The viscosity, the degree of crystallization and $\mathrm{pH}$ sensitivity of PVA cryogels changes over time, which leads to poor mechanical properties. Also, in comparison with other hydrogels, PVA hydrogels weakly adsorbed the proteins resulting in low cell adhesion, which, in the opinion of some authors, makes them less effective in the treatment of cartilage defects by the matrix-associated autologous chondrocyte transplantation [63]. 
Therefore, many PVA copolimers have been synthesized up to now. PVA (50\%) and silk fibroin $(50 \%)$ copolymer hydrogel was successfully used in tissue engineering of auricular cartilage, so further preclinical research with this new biomaterial is expected [64]. Thus, important for the context of this paper is that PVA copolymers with graphene [40] chitosan [65, 66], graphene and chitosan [44] are also described. Initial studies of the biocompatibility of porous PVA/chitosan hydrogel composite designed for tissue engineering scaffold showed that this material has no toxicity, but after muscle implantation, there was a stronger inflammatory reaction on the $4^{\text {th }}$ week, compared with porous PVA/nano-hydroxyapatite or porous PVA [67]. However, one recent study has shown that PVA/chitosan composite hydrogel can be used as a carrier for mesenchymal stem cells during focal cartilage defect therapy [65]. In novel nanocomposites based on chitosan-polyvinyl alcohol (CHI-PVA) and graphene oxide (GO), GO reinforced CHI-PVA engineering [40,44].

PVA is one of the most frequently and the oldest synthetic polymer employed as wound dressings. However, PVA hydrogel has inadequate elasticity, a stiff membrane, a relatively poor barrier property to bacterial penetration, sometimes poor mechanical stability and incomplete hydrophilic characteristics which restrict its use alone as a wound dressing polymeric membrane. Among the various hydrogels described in literature, hydrogels prepared using PVA blended with some natural polysaccharides and some other synthetic ones, including chitosan, graphene and Ag nanoparticles (AgNPs), are attractive and the most widespread route of membranes synthesis, because of the abundance of such polymers, easy for chemical derivatization or modification, and usually good biocompatible propreties [68]. However, these nanomaterials may potentially be risky for human health. Therefore, it is necessary to thoroughly examine their biocompatibility under in vivo conditions.

The introduction of AgNPs into polymer/copolymer hydrogels increases their antimicrobial activity, and the incorporation of graphene increases their mechanical properties. These materials are not biodegradable, so their use is recommended for surface wound treatment or as soft tissue implants. It was found that out of all metals with antimicrobial properties, silver had the most effective antibacterial action and lowest toxicity to animal cells [68]. However, the potential toxic effects of AgNPs on the circulatory, respiratory, central nervous system, liver and skin should not be forgotten. There is an increased trend for reduced usage of antibiotics in both humans and animals, as well as antibiotics in animal production. Numerous studies on the properties and possibilities of the application of the hybrid PVA/AgNPs material $[55,69]$, proved its advantages for topical therapeutic use in the experimental creamy formula with silver, suitable for recovery of the microbial homeostasis in animals.

Graphene-based composite hydrogels, in which graphene is produced from graphene oxide, exhibit antibacterial activity particularly against Gram-negative bacteria [38]. Additionally, the presence of AgNPs in composite hydrogels with graphene accelerates the rate of wound healing in animal models [70]. Recently, the novel PVA/graphene oxide/starch/Ag polymer nanocomposite film was successfully produced for 
biomedical use [43]. Incorporation of GO nanoparticles into PVA/starch/Ag films significantly increased the antimicrobial activity of films according to Gram-positive and negative bacteria. Contrary, some work suggests possible direct toxic effects of oxidized graphene to human osteoblasts [71] and respiratory system, i.e. exacerbation of allergic asthma [72]. However, a combination of GO with PVA reduces both the proliferation delay and the internal cell complexity alterations induced by GO on human osteoblasts, increases both cell viability and IL-6 levels, reducing both apoptosis and intracellular ROS content when compared to simple blending of both materials. The use of this strategy to modulate the biointerface reduces the toxic effects of graphene while preserving the reinforcement characteristics for application in tissue engineering scaffolds, and has enormous interest for polymer/graphene biomaterials development [71].

There are no published studies of in vivo biocompatibility of novel silver/poly(vinyl alcohol)/graphene and silver/poly(vinyl alcohol)/chitosan/graphene hydrogels aimed for medical applications. In this paper, we have shown for the first time the soft tissue response of novel silver-doped/PVA/Gr and PVA/CHI/Gr nanocomposite hydrogels aimed for medical applications. These novel hydrogels were produced by in situ electrochemical syntheses of silver nanoparticles in adequate matrixes as we described in our previously published works [30,37-39]. The results of our present study show that each of the TIrI scores, the leukocyte number around the implanted materials and capsule thickness were gradually decreased during 60 days follow-up. At the end-point of follow-up, Ag/PVA/CHI/Gr implant was surrounded with a thinner capsule, while both the TIrI scores and number of leukocytes of the periimplant zone were greater compared to $\mathrm{Ag} / \mathrm{PVA} / \mathrm{Gr}$ implant, similar to the results of other investigations of porous PVA/chitosan hydrogels [67] or PVA/graphene oxide/ starch/Ag polymer nanocomposite films [43]. Despite the observed differences, we can conclude that our in vivo experiment suggested that both novel hydrogels were biocompatible and potentially suitable for medical use.

\section{CONCLUSION}

The results of histological analyses of in vivo soft tissue applications of $\mathrm{Ag} / \mathrm{PVA} /$ $\mathrm{Gr}$ and $\mathrm{Ag} / \mathrm{PVA} / \mathrm{CHI} / \mathrm{Gr}$ hydrogel implants in rats indicated a satisfactory tissue response to these novel polymers. Together with our previous studies of their synthesis, and mechanical, thermal and biological in vitro properties, our present study indicated that both $\mathrm{Ag} / \mathrm{PVA} / \mathrm{Gr}$ and $\mathrm{Ag} / \mathrm{PVA} / \mathrm{CHI} / \mathrm{Gr}$ are promising biomaterials for use in human and veterinary medicine.

\section{Acknowledgments}

This study was supported by Ministry of Education, Science and Technological Development of Republic of Serbia grant projects III 45019 and OI 175064, and 
Basic Science Research Program through the National research Foundation of Korea - Ministry of Education, Science and Technology grand project 2016R1A2B4016034.

\section{Authors' contributions}

TLB and VT were participated in the study design, performed the experimental work, an analyzed the data, and drafted the manuscript. VMS, KN and KYR carried otu the novel hydrogels synthesis, as well as supervised and facilitated in the overall write-up. DM, BBP, IM and ND participated in the study design and performed the experimental work, IM helped in prepared figures. All authors read and approved the final manuscript.

\section{Declaration of conflicting interests}

The author(s) declared no potential conflicts of interest with respect to the research, authorship, and/or publication of this article.

\section{REFERENCES}

1. vonRecum AF: Hand book of biomaterials evaluation: scientific, technical and clinical testing of implant materials. 2nd ed. London, UK: Taylor \& Francis; 1999.

2. Kumar A, Jaiswal M: Design and in vitro investigation of nanocomposite hydrogel based in situ spray dressing for chronic wounds and synthesis of silver nanoparticles using green chemistry. J Appl Polym Sci 2016, 133:1-14.

3. Zhang D, Zhou W, Wei B, Wang X, Tang R, Nie J, Wang J: Carboxyl-modified poly (vinyl alcohol)-crosslinked chitosan hydrogel films for potential wound dressing. Carbohyd Polym 2015, 125:189-199.

4. Baker MI, Walsh SP, Schwartz Z, Boyan BD: A review of polyvinyl alcohol and its uses in cartilage and orthopedic applications. J Biomed Mater Res - Part B Appl Biomater 2012, 100 B:1451-1457.

5. Kanimozhi K, Basha SK, Kumari VS: Processing and characterization of chitosan/PVA and methylcellulose porous scaffolds for tissue engineering. Mater Sci Eng C 2016, 61:484 491.

6. Oh SH, An DB, Kim TH, Lee JH: Wide-range stiffness gradient PVA/HA hydrogel to investigate stem cell differentiation behavior. Acta Biomater 2016, 35:23-31.

7. Koehler J, Brandl FP, Goepferich AM: Hydrogel wound dressings for bioactive treatment of acute and chronic wounds. Eur Polym J 2018, 100:1-11.

8. Schmedlen RH, Masters KS, West JL: Photocrosslinkable polyvinyl alcohol hydrogels that can be modified with cell adhesion peptides for use in tissue engineering. Biomaterials 2002, 23:4325-4332.

9. Jiang S, Liu S, Feng W: PVA hydrogel properties for biomedical application. J Mech Behav Biomed Mater 2011, 4:1228-1233. 
10. Peppas NA, Huang Y, Tores-Lugo M, Ward JH, Zhang J: Physicochemical Foundations and Structural Design of Hydrogels in Medicine and Biology. Annu Rev Biomed Eng 2000, 2:9-29.

11. Puspitasari T, Raja KML, Pangerteni DS, Patriati A, Putra EGR: Structural Organization of Poly(vinyl alcohol) Hydrogels Obtained by Freezing/Thawing and $\Gamma$-Irradiation Processes: A Small-Angle Neutron Scattering (\{SANS\}) Study. Procedia Chem 2012, 4:186-193.

12. Cheung RCF, Ng TB, Wong JH, Chan WY: Chitosan: An update on potential biomedical and pharmaceutical applications. Mar Drugs 2015, 13:5156-5186.

13. Kumar MNVR, Muzzarelli RAA, Muzzarelli C, Sashiwa H, Domb AJ: Chitosan chemistry and pharmaceutical perspectives. Chem Rev 2004, 104:6017-6084.

14. Jayakumar R, Prabaharan M, Kumar PS, Nair SV, Tamura H: Biomaterials based on chitin and chitosan in wound dressing applications. Biotechnol Adv 2011, 29:322-337.

15. Mi FL, Wu YB, Shyu SS, Schoung JY, Huang YB, Tsai YH, Hao JY: Control of wound infections using a bilayer chitosan wound dressing with sustainable antibiotic delivery. J Biomed Mater Res 2002, 59:438-449.

16. Mi FL, Shyu SS, Wu YB, Lee ST, Shyong JY, Huang RN. Fabrication and characterization of a sponge-like asymmetric chitosan membrane as a wound dressing. Biomaterials 2001, 22:165-173.

17. Lu S, Gao W, Gu HY: Construction, application and biosafety of silver nanocrystalline chitosan wound dressing. Burns 2008, 34:623-628.

18. Madihally SV, Matthew HWT: Porous chitosan scaffolds for tissue engineering. Biomaterials 1999, 20:1133-1142.

19. Khor E, Lim LY: Implantable applications of chitin and chitosan. Biomaterials 2003, 24:2339-2349.

20. Mishra SK, Ferreira JMF, Kannan S: Mechanically stable antimicrobial chitosan-PVA-silver nanocomposite coatings deposited on titanium implants. Carbohydr Polym 2015, 121:3748.

21. Pishbin F, Simchi A, Ryan MP, Boccaccini AR: Electrophoretic deposition of chitosan/45S5 Bioglass composite coatings for orthopaedic applications. Surf Coatings Technol 2011, 205:5260-5268.

22. Venkatesan J, Kim SK: Chitosan composites for bone tissue engineering - An overview. Mar Drugs 2010, 8:2252-2266.

23. Felt O, Buri P, Gurny R: Chitosan: A unique polysaccharide for drug delivery. Drug Dev Ind Pharm 1998, 24:979-993.

24. Agnihotri SA, Mallikarjuna NN, Aminabhavi TM: Recent advances on chitosan-based micro- and nanoparticles in drug delivery. J Control Release 2004, 100:5-28.

25. Bhattarai N, Gunn J, Zhang M: Chitosan-based hydrogels for controlled, localized drug delivery. Adv Drug Deliv Rev 2010, 62:83-99.

26. Alt V, Bechert T, Steinrucke P, Wagener M, Seidel P, Dingeldein E, Domann E, Schnettler $\mathrm{R}$ : An in vitro assessment of the antibacterial properties and cytotoxicity of nanoparticulate silver bone cement. Biomaterials 2004, 25:4383-4391.

27. Lok CN, Ho CM, Chen R, He QY, Yu WY, Sun H, Tam PKH, Chiu JF, Che CM: Silver nanoparticles: partial oxidation and antibacterial activities. J Biol Inorg Chem 2007, 12:527-534.

28. Chou KS, Ren CY: Synthesis of nanosized silver particles by chemical reduction method. Mater Chem Phys 2000, 64:241-246. 
29. Nešović K, Kojić V, Rhee KY, Mišković-Stanković V: Electrochemical synthesis and characterization of silver doped poly(vinyl alcohol)/chitosan hydrogels. Corrosion 2017, 73:1437-1447.

30. Twu YK, Chen YW, Shih CM: Preparation of silver nanoparticles using chitosan suspensions. Powder Technol 2008, 185:251-257.

31. Balandin AA, Ghosh S, Bao W, Calizo I, Teweldebrhan D, Miao F, Lau CN: Superior Thermal Conductivity of Single-Layer Graphene 2008. Nano Lett 2008, 8:902-907.

32. Weiss NO, Zhou H, Liao L, Liu Y, Jiang S, Huang Y, Duan X: Graphene: An emerging electronic material. Adv Mater 2012, 24:5782-5825.

33. Surudžić R, Janković A, Mitrić M, Matić I, Juranić ZD, Živković Lj, Mišković-Stanković V, Rhee KY, Park SJ, Hui D: The effect of graphene loading on mechanical, thermal and biological properties of poly(vinyl alcohol)/graphene nanocomposites. J Ind Eng Chem 2016, 34:250-257.

34. Yang JM, Wang SA: Preparation of graphene-based poly(vinyl alcohol)/chitosan nanocomposites membrane for alkaline solid electrolytes membrane. J Memb Sci 2015, 477:49-57.

35. Wang T, Li Y, Geng S, Zhou C, Jia X, Yang F, Zhang L, Ren X, Yang H: Preparation of flexible reduced graphene oxide/poly(vinyl alcohol) film with superior microwave absorption properties. RSC Adv 2015, 5:88958-88964.

36. Hegab HM, Elmekawy A, Zou L, Mulcahy D, Saint CP, Ginić-Marković M: The controversial antibacterial activity of graphene-based materials. Carbon 2016, 105:362-376.

37. Abudabbus MM, Jevremović I, Janković A, Perić-Grujić A, Matić I, Vukašinović-Sekulić M, Hui, D, Rhee, KY, Mišković-Stanković, V: Biological activity of electrochemically synthesized silver doped polyvinyl alcohol/graphene composite hydrogel discs for biomedical applications. Compos Part B Eng 2016, 104:26-34.

38. Abudabbus MM, Jevremović I, Nešović K, Perić-Grujić A, Rhee KY, Mišković-Stanković V: In situ electrochemical synthesis of silver-doped poly(vinyl alcohol)/graphene composite hydrogels and their physico-chemical and thermal properties. Compos Part B Eng 2018, 140:99-107.

39. Nešović K, Abudabbus MM, Rhee KY, Mišković-Stanković V: Graphene Based Composite Hydrogel for Biomedical Applications. Croat Chem Acta 2017, 90:207-213.

40. Wang J, Wang X, Xu C, Zhang M, Shang X: Preparation of graphene/poly(vinyl alcohol) nanocomposites with enhanced mechanical properties and water resistance. PolymInt 2011, 60:816-822.

41. Xue R, Xin X, Wang L, Shen J, Ji F, Li W, Jia C, Xu G: A systematic study of the effect of molecular weights of polyvinyl alcohol on polyvinyl alcohol-graphene oxide composite hydrogels. PhysChemChemPhys 2015, 17:5431-5440.

42. Abudabbus MM, Jevremović I, Janković A, Perić-Grujić A, Matić I, Vukašinović-Sekulić M, Hui D, Rhee K.Y, Mišković-Stanković V: Biological activity of electrochemically synthesized silver doped polyvinyl alcohol/graphene composite hydrogel discs for biomedical applications. Compos Part B Eng 2016, 104:26-34.

43. Usman A, Hussain Z, Riaz A, Khan AN: Enhanced mechanical, thermal and antimicrobial properties of poly(vinyl alcohol)/graphene oxide/starch/silver nanocomposites films. CarbohydrPolym 2016, 153:592-599.

44. Pandele AM, Ionita M, Crica L, Dinescu S, Costache M, Iovu H: Synthesis, characterization, and in vitro studies of graphene oxide/chitosan-polyvinyl alcohol films. CarbohydrPolym 2014, 102:813-820. 
45. Peppas NA, Bures P, Leobandung W, H Ishikawa: Hydrogels in pharmaceutical formulations. Eur J Pharm Biopharm 2000, 50:27-46.

46. Muppalaneni S, Omidian H: Polyvinyl alcohol in medicine and pharmacy: A Perspective. J Devel Drugs 2013, 2:1-5

47. Hyon SH, Cha WI, Ikada Y, Kita M, Ogura Y, Honda Y: Poly (vinyl alcohol) hydrogels as soft contact lens material. J BiomaterSciPolym Ed 1994, 5:397-406.

48. Jiang H, Zuo Y, Zhang L, Li J, Zhang A, Li Y, Yang X: Property-based design: optimization and characterization of polyvinyl alcohol (PVA) hydrogel and PVA-matrix composite for artificial cornea. J Mater Sci Mater Med 2014, 25:941-952.

49. Shokrgozar MA, Bonakdar S, Dehghan MM, Emami SH, Montazeri L, Azari S, Rabbani M: Biological evaluation of polyvinyl alcohol hydrogel crosslinked by polyurethane chain for cartilage tissue engineering in rabbit model. J Mater Sci Med 2013, 24:2449-2460.

50. Hayes JC, Kennedy JE: An evaluation of the biocompatibility properties of a salt-modified polyvinyl alcohol hydrogel for a knee meniscus application. Mater SciEng C Mater BiolAppl 2016, 59:894-900.

51. Kobayashi M, Togushida J, Oka M: Development of polyvinyl alcohol-hydrogel shields with a high water content for tendon injury repair. J Hand Surg Br 2001, 26:436-440.

52. Kobayashi M, Oka M: Composite device for attachment o polyvinyl alcohol-hydrogel to underlying bone. Artif Organs 2004, 28:734-738.

53. Guo Y, Guo J, Bai D, Wang H, Zheng X, Guo W, Tian W: Hemiarthroplasty of the shoulder joint using a custom-designed high-density nano-hydroxyapatite/ polyamide prosthesis with a polyvinyl alcohol hydrogel humeral head surface in rabbits. Artif Organs 2014, 38:580-586.

54. Deerenberg EB, Mulder IM, Ditzel M, Slieker JC, Bemelman WA, Jeekel J, Lange JF: Polyvinyl alcohol hydrogel decreases formation of adhesions in a rat model of peritonitis. Surg Infect (Larchmt) 2012, 13:321-325.

55. Moretto A, Tesolin L, Marsilio F, Schiavon M, Berna M, Veronese FM: Slow release of two antibiotics of veterinary interest from PVA hydrogels. Farmaco 2004, 59:1-5.

56. Basak P, Adhikari B: Poly (vinyl alcohol) hydrogels for $\mathrm{pH}$ dependent colon targeted drug delivery. J Mater Sci Mater Med 2009, 20(Suppl 1):137-146.

57. Kim TH, An DB, Oh SH, Kang MK, Song HH, Lee JH: Creating stiffness gradient polyvinyl alcohol hydrogel using a simple gradual freezing-thawing method to investigate stem cell differentiation behaviors. Biomaterials 2015, 40:51-60.

58. Li P, Jiang S, Yu Y, Yang J, Yang Z: Biomaterial characteristics and application of silicone rubber and PVA hydrogels mimicked in organ groups for prostate brachytherapy. J MechBehav Biomed Mater 2015, 49:220-234.

59. Alexandre N, Amorim I, Caseiro AR, Pereira T, Alvites R, Rêma A, Gonçalves A, Valadares G, Costa E, Santos-Silva A, Rodrigues M, Lopes MA, Almeida A, Santos JD, Maurício AC, Luís AL: Long term performance evaluation of small-diameter vascular grafts based on polyvinyl alcohol hydrogel and dextran and MSCs-based therapies using the ovine preclinical animal model. Int J Pharm 2017, 523:515-530.

60. Scaretta FV: 5 to 8 years follow-up of knee chondral defects treated by PVA-H hydrogel implants. Eur Rev Med PharmacolSci 2013, 17:3031-3038.

61. Taleb C, Berner S, Mantovani Ruggiero G: First metacarpal resurfacing with polyvinyl alcohol implant in osteoarthritis: preliminary study. Chir Main 2014, 33:189-195. 
62. Daniels TR, Younger AS, Penner MJ, Wing KJ, Miniaci-Coxhead SL, Pinsker E, Glazebrook M: Midterm outcomes of polyvinyl alcohol hydrogel hemiarthroplasty of the first metatarso-phalangeal joint in advanced hallux rigidus. Foot Ankle Int 2017, 38:243-247.

63. Baker MI, Walsh SP, Schwartz Z, Boyan BD: A review of polyvinyl alcohol and its uses in cartilage and orthopedic applications. J Biomed Mater Res B ApplBiomater 2012, 100:1451-1457.

64. Lee JM, Sultan MT, Kim SH, Kumar V, Yeon YK, Lee JH: Artificial auricular cartilage using silk fibroin and polyvinyl alcohol hydrogel. Int J MolSci 2017, 18:1707.

65. Dashtdar H, Murali MR, Abbas AA, Suhaeb AM, Selvaratnam L, Tay LX, Kamarul T: PVAchitosan composite hydrogel versus alginate beads as a potential mesenchymal stem cell carrier for the treatment of focal cartilage defects. Knee Surg Sports TraumatolArthrosc $2015 ; 23: 1368-1377$.

66. Kamoun EA, Kenawy ES, Chen X: A review on polymeric hydrogel membranes for wound dressing applications: PVA-based hydrogel dressings. J Adv Res 2017, 8:217-233.

67. Wu JQ, Liu Y, Yang TF, Mu YH, Guo T, Li YB: Porous polyvinyl alcohol hydrogel composite prepared and studied initially for biocompatibility. Sichuan Da XueXueBao Yi Xue Ban 2007, 38:705-708, 724.

68. Korbekandi H, Iravani S: Silver Nanoparticles. In: The Deliveri of Nanoparticles. Rijeka, Croatia: Intech Open; 2012, 3-36.

69. Pencheva D, Bryaskova R, Kantardjiev T: Polyvinyl alcohol/silver nanoparticles (\{PVA/ AgNPs $\}$ ) as a model for testing the biological activity of hybrid materials with included silver nanoparticles. Mater SciEng C 2012, 32:2048-2051.

70. Fan Z, Liu B, Wang J, Zhang S, Lin Q, Gong P, Ma L, Yang S: A novel wound dressing based on Ag/graphene polymer hydrogel: effectively kill bacteria and accelerate wound healing. AdvFunct Mater 2014, 24:3933-3943.

71. Linares J, Matesanz MC, Feito MJ, Salavagione HJ, Martínez G, Gómez-Fatou M, Portolés MT: Influence of the covalent immobilization of graphene oxide in poly(vinyl alcohol) on human osteoblast response. Colloids Surf B Biointerfaces 2016, 138:50-59.

72. Shang S, Li J, Zhao Y, Xi Z, Lu Z, Li B, Yang X, Li R: Oxidized graphene-aggravated allergic asthma is antagonized by antioxidant vitamin $\mathrm{E}$ in Balb/c mice. Environ SciPollut Res Int 2017, 24:1784-1793. 


\section{ODGOVOR MEKOG TKIVA NA IMPLANTACIJU NOVOSINTETISANIH SREBRO/POLIVINIL ALKOHOL/ GRAFEN I SREBRO/POLIVINIL ALKOHOL/HITOZAN/ GRAFEN HIDROGELOVA NAMENJENIH BIOMEDICINSKOJ UPOTREBI- PRVO ISKUSTVO}

LUŽAJIĆ BOŽINOVSKI Tijana, MARKOVIĆ Danica, TODOROVIĆ Vera, PROKIĆ Bolka Bogomir, MILOŠEVIĆ Ivan, DRNDAREVIĆ Neda, NEŠOVIĆ Katarina, KYONG Yop Rhee, MIŠKOVIĆ-STANKOVIĆ Vesna

$\mathrm{U}$ ovom radu prvi put su prikazani rezultati in vivo ispitivanja rekcije mekog tkiva na nove nanokompozitne hidrogelove implantirane u potkožno tkivo pacova, koji su predviđeni za medicinsku primenu. Novi nanokompozitni hidrogelovi - srebro/ poli(vinil alkohol)/grafen (Ag/PVA/Gr) i srebro/poli(vinil alkohol)/hitozan/grafen (Ag/PVA/CHI/Gr) su proizvedeni in situ elektrohemijskom sintezom nanočestica srebra u polimernim matricama, u obliku diskova, kao što je opisano u našim prethodno objavljenim radovima. Ag/PVA/Gr i Ag/PVA/CHI/Gr, kao i kontrolni Ag/ PVA, Ag/PVA/CHI i komercijalni Suprasorb ${ }^{\circ}$, implantirani su u potkožno tkivo pacova. Posle 7, 15, 30 i 60. dana od implantacije, izdvajani su implantati s okolnim tkivom, a zatim obrađeni za histološki pregled. Ispitivani su indeks iritacije tkiva (TIrI) prema ISO 10993-6, 2007, kao i broj leukocita u zoni neposredno oko implantata i debljina vezivnotkivne kapsule. Rezultati pokazuju da su se TIrI, broj leukocita oko implantiranih materijala i debljina kapsule postepeno smanjivali tokom perioda promatranja. Na kraju eksperimentalnog perioda, implantat od Ag/PVA/CHI/Gr imao je veću vrednost TIrI i veći broj leukocita u peri-implantnoj zoni, ali je bio okružen tanjom kapsulom, u poređenju sa implantatom od Ag/PVA/Gr. Međutim, i pored ovih razlika, možemo zaključiti da rezultati našeg in vivo eksperimenta sugerišu da su novi hidrogelovi biokompatibilni i prikladni za medicinsku upotrebu. 